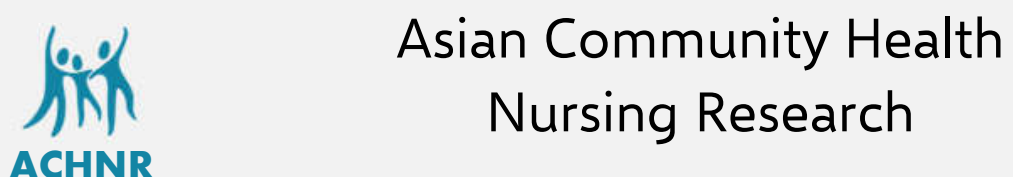

Asian Comm. Health Nurs. Res. 2019, 1(1), 20-27

\title{
Challenges and Assets for Promoting Early Childhood Development in Indonesia: A Health Statistics Review from a Community Health Perspective
}

\author{
Mayumi Mizutani 1*, Masumi Moriyama ${ }^{2}$, Heri Sugiarto ${ }^{3}$, Riyanto ${ }^{3}$, Maftuhah $^{4}$, and \\ Harumi Bando 5 \\ ${ }^{1}$ Department of Community Health Nursing, Mie University Graduate School of Medicine, Mie, Japan \\ 2 School of Nursing at Narita, International University of Health and Welfare, Chiba, Japan \\ ${ }^{3}$ Indramayu College of Health Science, Indramayu, Indonesia \\ 4 Syarif Hidayatullah State Islamic University Jakarta, Jakarta, Indonesia \\ 5 Faculty of Nursing, School of Medicine, Nara Medical University, Nara, Japan \\ *Correspondence: m-mizutani@nurse.medic.mie-u.ac.jp; \\ Review article
}

Received: November 19, 2018; Accepted: January 9, 2019; Published: February 3, 2019

https://doi.org/10.29253/achnr.2019.12011

\begin{abstract}
Background: Although early childhood development is important, there are limited health statistics reviews related to the early childhood development in Indonesia. This study organized statistical health information across 33 Indonesian provinces to assess ongoing challenges and existing assets for improving early childhood development. Information about early childhood development in Indonesia between 2007 and 2013 was obtained through data supplied by the Indonesian Ministry of Health and the Indonesian Central Bureau of Statistics. Methods: The information collected was organized into five domains of early childhood development: health, nutrition, responsive caregiving, early learning, and security and safety. Challenges and assets in Indonesia were assessed in terms of early childhood development. Results: Our results indicated that although the child mortality rate decreased between 2007 and 2013, it remained higher than the global average, with large disparities between provinces. Background factors influencing child mortality rates included the limited availability of health services, large catchment areas for puskesmas (community health centers), parents' limited caregiving responsiveness, and limited opportunities for parents to achieve advanced education. However, our results also revealed several important assets, including the existence of community health posts, alert village programs, community volunteers, and a large number of nurses and midwives; Conclusions: To improve early childhood development in Indonesia, it is important to empower parents to utilize these community health-related assets. Nurses and kaders (community health volunteers) should promote parents' enhanced awareness of child health and development.
\end{abstract}

Keywords: child development; child health; community health nursing; health promotion; Indonesia

\section{Introduction}

Child health is an ongoing global health and development priority and was highlighted as a target of Goal 3 of the UN Sustainable Development Goals (SDG). SDG indicator 3.2.1. aims to reduce the underfive mortality rate to 25 per 1,000 live births or lower by 2030 (United Nations Statistics Division, n.d.). However, there are regional variations internationally and domestically, and child health remains a significant problem, particularly in low- and middle-income countries. According to the World Health

Copyright $(2019$ by the authors. Submitted for possible open access publication under the terms and conditions of the Creative Commons Attribution (CC BY) license. 
Organization, Africa (81.3/1,000 live births), the Eastern Mediterranean region $(52.0 / 1,000)$, and Southeast Asia (42.5) have relatively high under-five mortality rates, whereas the Americas (14.7), the Western Pacific (13.5), and Europe (11.3) have lower child mortality rates (World Health Organization, 2017b). This study focuses on Indonesia, a middle-income country in Southeast Asia with a relatively high under-five mortality rate (27.2) (World Health Organization, 2017b), which is the fifth highest among the 10 Association of Southeast Asian Nations member states (United Nations Children's Fund, 2017). Indonesia faces challenges to improving child health due to widening inequalities between provinces (Hodge, Firth, Marthias, \& Jimenez-Soto, 2014).

Health, nutrition, and learning are critically important during early childhood due to their implications for adult health status (Adair et al., 2013; Victora et al., 2008; World Health Organization, 2017a). The nurturing care provided by parents, families, and other community members is important for improving children's health and development (Britto et al., 2017; Winston \& Chicot, 2016). Early childhood development (ECD) is particularly important for acquiring fundamental physical, emotional, and social skills (Irwin, Siddiqi, \& Hertzman, 2007). The acquisition of these skills is influenced by the five domains of nurturing care: health, nutrition, responsive caregiving, early learning, and security and safety (Black et al., 2017).

Several studies have identified common factors that prevent the equitable distribution of child health, growth, and development in Indonesia, which were subsequently summarized in a systematic review. These factors included the insufficiency of the rural healthcare system, parents' low health literacy, and mothers' limited decision-making power (Schröders, Wall, Kusnanto, \& Ng, 2015). Other studies pointed to the limited utilization and availability of health posts (Andriani, Liao, \& Kuo, 2016; Sahanggamu, Purnomosari, \& Dillon, 2017). However, there is limited information available on the health aspects of childcare (Boothby \& Stark, 2011), and no study to date has organized statistical health information related to the five ECD domains for Indonesia's 33 provinces. It is also important to focus on assets to identify solutions for improving suboptimal ECD in resource-limited settings in low- and middle-income countries.

This study organized ECD-related statistical health information across 33 Indonesian provinces. The data were used to assess the ongoing challenges facing current child healthcare provision from a community health perspective, alongside the existing assets available to improve ECD in Indonesia.

\section{Methods}

Statistical health information related to ECD from 33 provinces in Indonesia was obtained online from the Indonesia Demographic and Health Survey (2007 and 2012) (Indonesian Central Bureau of Statistics, 2008, 2013), the Indonesia Health Profile $(2007,2010$, and 2013) conducted by the Indonesian Ministry of Health (Indonesian Ministry of Health, 2008b, 2011, 2014a), the Basic Health Research Survey (2007, 2010, and 2013) conducted by the Indonesian Ministry of Health (Indonesian Ministry of Health, 2008a, 2010a, 2013), and the Indonesian Central Bureau of Statistics (Indonesian Central Bureau of Statistics, n.d.-a, n.d.-b). The mean, minimum, and maximum values were calculated using Microsoft Excel 2016 (Microsoft, Redmond, WA, USA). Additional information on background indicators for child healthcare systems was obtained online from the Indonesian Ministry of Health (Indonesian Ministry of Health, 2004, 2010b, 2014b, 2015, 2016, 2017), the World Health Organization Country Office for Indonesia (World Health Organization Country Office for Indonesia, n.d.), the World Health Organization (World Health Organization, 2017b), and other official organizations (Federal Ministry for Economic Cooperation and Development, 2011). The health statistics and other information collected were then organized into the five domains of nurturing care necessary for ECD: health, nutrition, responsive caregiving, early learning, and security and safety. Challenges and assets for promoting ECD in Indonesia were discussed with reference to the findings.

\section{Results}

The health statistics and information collected and organized into the five ECD domains in Indonesia are described below in detail. Key indicators are presented in Table 1. 


\subsection{Health}

The Indonesian Ministry of Health's Strategic Plan (2015-2019) emphasizes the importance of improving health and nutrition through community empowerment (Indonesian Ministry of Health, 2015). Although some child health indicators have improved, our results revealed that disparities between provinces remain. The mean under-five mortality rate decreased from 57.2 (per 1,000 live births) in 2007 to 50.8 in 2012 (Indonesian Central Bureau of Statistics, 2008, 2013), but the difference between provinces ranged from 28.0 (Riau) to 115.0 (Papua).

Primary healthcare services are provided according to regulations governing minimum health service standards set by the Indonesian Ministry of Health (Indonesian Ministry of Health, 2016). Local governments provide primary healthcare services for every member of the population, including newborn babies, infants, and children. These services include delivery services by a midwife or a doctor; neonatal home visits; and complete basic immunization by a midwife, nurse, or doctor (Indonesian Ministry of Health, 2016). Although the indicators improved from 2007 to 2013, not all children were receiving important health services, such as a birth attended by health workers (88.8\%), neonatal home visits (84.1\%), and complete immunization (55.5\%) in 2013 (Indonesian Ministry of Health, 2013, 2014a). Moreover, these inadequacies also differed across provinces.

Primary healthcare services are provided at puskesmas (community health centers). The catchment population and area per puskesmas differs across provinces. The mean catchment population decreased from 22,429 in 2007 to 21,360 in 2013, ranging from 5,921 (West Papua) to 50,100 (Banten) in 2013, and the catchment area ranged from $2 \mathrm{~km}^{2}$ (Jakarta) to $921 \mathrm{~km}^{2}$ (East Kalimantan) in 2013 (Indonesian Ministry of Health, 2008b, 2011, 2014a). In addition to puskesmas, there are community-based health posts, called posyandu, where child growth and development are monitored by nurses, midwives, or kaders (community health volunteers). The mean catchment household number per posyandu in 2013 was 245 households, ranging from 125 (East Nusa Tenggara) to 606 (Jakarta) (Indonesian Central Bureau of Statistics, n.d.-b; Indonesian Ministry of Health, 2014a).

Although the number of health workers per 100,000 people in the population increased from 2010 to 2013 (Indonesian Ministry of Health, 2011, 2014a), the increase was not evenly distributed. For example, the mean number of nurses per 100,000 people in 2013 was 166.2, ranging from 65.7 (North Sumatra) to 320.1 (West Papua). Nurses and midwives constituted the greatest proportion of health professionals. In addition to health professionals, kaders provide support for child healthcare in each village (Indonesian Ministry of Health, 2014b).

\subsection{Nutrition}

The proportion of children with low birth weight decreased slightly from $12.6 \%$ in 2007 to $10.7 \%$ in 2013 (Indonesian Ministry of Health, 2008b, 2014a). The proportion of children with stunted growth remained high, increasing from $37.7 \%$ in 2007 to 38.2\% in 2013 (Indonesian Ministry of Health, 2008b, 2014a), and has not yet reached the 2019 target (28\%) set by the Indonesian Ministry of Health (Indonesian Ministry of Health, 2015). Meanwhile, some children (11.1\% in 2013) are overweight (Indonesian Ministry of Health, 2014a).

\subsection{Responsive caregiving}

Based on a decree from the Indonesian Ministry of Health in 2004 (Indonesian Ministry of Health, 2004), every mother should be given a maternal and child health book during her first prenatal healthcare visit. The book contains useful information about early childhood development, including child weight and immunization information. However, in 2013, only $29.8 \%$ of parents with 0 - to 59month-old children had one of these books in their possession, ranging from $11.3 \%$ (West Papua) to 56.1\% (Yogyakarta) (Indonesian Ministry of Health, 2013). 
Table 1. Health statistics for early childhood development across 33 provinces in Indonesia.

\begin{tabular}{|c|c|c|c|c|c|c|c|c|c|c|c|c|c|c|c|}
\hline & \multicolumn{5}{|c|}{2007} & \multicolumn{5}{|c|}{2010} & \multicolumn{5}{|c|}{2013} \\
\hline & Mean & Min & Province ${ }^{\ddagger}$ & Max & Province ${ }^{\ddagger}$ & Mean & Min & Province ${ }^{\ddagger}$ & Max & Province ${ }^{\ddagger}$ & Mean & Min & Province ${ }^{\ddagger}$ & Max & Province ${ }^{\ddagger}$ \\
\hline \multicolumn{16}{|l|}{ Health } \\
\hline Neonatal mortality rate $(/ 1,000 \text { births })^{\dagger}$ & 23.3 & 13.0 & C. Kalimantan & 46.0 & W. Sulawesi & - & - & - & & - & 22.3 & 12.0 & E.Kalimantan & 37.0 & N. Maluku \\
\hline Infant mortality rate $(/ 1,000 \text { births })^{\dagger}$ & 42.8 & 19.0 & Yogyakarta & 74.0 & W. Sulawesi & - & - & - & & - & 38.9 & 21.0 & E.Kalimantan & 74.0 & W. Papua \\
\hline Under -5 child mortality $(/ 1,000 \text { births })^{\dagger}$ & 57.2 & 22.0 & Yogyakarta & 96.0 & W. Sulawesi & - & - & - & & - & 50.8 & 28.0 & Riau & 115.0 & Papua \\
\hline Births attended by health worker (\%) & 74.0 & 33.7 & W. Papua & 95.1 & Bali & 80.6 & 25.2 & Papua & 98.8 & Bali & 88.8 & 33.3 & Papua & 99.9 & C. Java \\
\hline Complete neonatal home visit (\%) & 73.4 & 24.7 & Papua & 97.6 & Bali & 71.5 & 25.1 & S. Sulawesi & 98.1 & Bali & 84.1 & 25.4 & Papua & 95.4 & C. Java \\
\hline Population (/puskesmas) & 22429.4 & 8193.5 & Papua & 52352.2 & Banten & 21514.2 & 7173.8 & W. Papua & 48996.2 & Banten & 21359.9 & 5921.1 & W. Papua & 50100.1 & Banten \\
\hline Area $\left(\mathrm{km}^{2}, /\right.$ puskesmas $)$ & 323.7 & 1.9 & Jakarta & 1296.9 & Papua & 275.6 & 1.9 & Jakarta & 1074.2 & Papua & 244.3 & 2.0 & Jakarta & 921.3 & E.Kalimantan \\
\hline Household (/posyandu) & 237.6 & 33.6 & W. Sulawesi & 751.5 & Riau Islands & 245.8 & 150.6 & W. Papua & 601.2 & Jakarta & 245.4 & 125.2 & E. NT & 606.2 & Jakarta \\
\hline Doctor (/100,000 people) & - & - & - & - & - & 18.6 & 6.0 & Banten & 61.5 & Jakarta & 35.4 & 18.7 & Lampung & 86.6 & Jakarta \\
\hline Nurse $(/ 100,000$ people) & - & & - & - & - & 108.2 & 24.7 & Banten & 262.7 & Jakarta & 166.2 & 65.7 & N. Sumatera & 320.1 & W. Papua \\
\hline Midwife (/100,000 people) & - & - & - & - & - & 54.6 & 19.7 & Jakarta & 145.0 & Aceh & 71.7 & 28.8 & Jakarta & 204.3 & Aceh \\
\hline \multicolumn{16}{|l|}{ Nutrition } \\
\hline Low birth weight (age $\leq 5$ years, $\%$ ) & 12.6 & 5.8 & Bali & 27.0 & Papua & 12.5 & 6.0 & $\begin{array}{l}\text { W. } \\
\text { Sumatera }\end{array}$ & 19.2 & E. NT & 10.7 & 7.2 & N. Sumatera & 16.8 & C. Sulawesi \\
\hline Stunting children (age $\leq 5$ years, \%) & 37.7 & 26.1 & Riau Islands & 46.7 & E.NT & 35.5 & 22.5 & Yogyakarta & 58.4 & E. NT & 38.2 & 26.3 & Riau Islands & 51.7 & E. NT \\
\hline Wasting children (age $\leq 5$ years, \%) & 15.0 & 9.0 & $\begin{array}{l}\text { W. Java, } \\
\text { Yogyakarta }\end{array}$ & 22.1 & Riau & 13.5 & 7.5 & BBI & 20.0 & Jambi & 12.6 & 8.8 & Bali & 18.7 & $\begin{array}{l}\text { W. } \\
\text { Kalimantan }\end{array}$ \\
\hline Overweight (age $\leq 5$ years, $\%$ ) & 12.3 & 6.8 & Gorontalo & 20.9 & S. Sumatera & 12.5 & 5.0 & N. Maluku & 19.6 & Jakarta & 11.1 & 6.4 & Maluku & 21.4 & Lampung \\
\hline \multicolumn{16}{|l|}{ Responsive caregiving } \\
\hline MCH book ownership (age 0-59 months, \%) & 13.3 & 2.4 & N. Sumatera & 42.7 & Yogyakarta & 23.7 & 6.6 & W.Papua & 56.7 & Yogyakarta & 29.8 & 11.3 & W. Papua & 56.1 & Yogyakarta \\
\hline Exclusive breastfeeding (age 0-5 months, \%) & - & - & - & - & - & 62.2 & 48.8 & E. Java & 78.3 & W. NT & 56.6 & 25.2 & Maluku & 79.7 & W. NT \\
\hline $\begin{array}{l}\text { Weighing frequency } \geq 4 \text { times during } 6 \text { months } \\
\text { (age 6-59 months, \%) }\end{array}$ & 44.5 & 21.4 & N. Sumatera & 78.5 & Yogyakarta & 41.2 & 21.2 & Jambi & 86.8 & Yogyakarta & - & & - & & - \\
\hline Smoking (age $\geq 10$ years, $\%$ ) & 29.0 & 24.2 & S.Kalimantan & 34.4 & Lampung & - & - & - & & - & 28.5 & 21.9 & Papua & 32.7 & W. Java \\
\hline Smoking at home (age $\geq 10$ years, $\%$ ) & 85.5 & 64.1 & Jakarta & 93.3 & C. Sulawesi & - & - & - & & - & 82.5 & 50.9 & Jakarta & 92.4 & W. Sulawesi \\
\hline \multicolumn{16}{|l|}{ Early learning } \\
\hline Primary school net enrollment (\%) & 92.9 & 80.9 & Papua & 95.8 & Aceh & 94.0 & 76.2 & Papua & 97.3 & Aceh & 94.7 & 72.6 & Papua & 98.8 & Yogyakarta \\
\hline Junior high school net enrollment (\%) & 64.1 & 48.7 & Papua & 76.4 & Aceh & 65.3 & 49.6 & Papua & 78.6 & Aceh & 70.7 & 45.8 & Papua & 83.3 & Riau Islands \\
\hline High school net enrollment (\%) & 45.7 & 33.3 & W. Sulawesi & 62.0 & Aceh & 46.6 & 34.0 & $\begin{array}{l}\text { W. } \\
\text { Sulawesi }\end{array}$ & 62.4 & Aceh & 55.2 & 36.7 & Papua & 67.6 & Riau Islands \\
\hline \multicolumn{16}{|l|}{ Security and safety } \\
\hline
\end{tabular}

Population living below the poverty line (\%) 40.8 Papua 3.5 2013.

‡ Province name abbreviations, C: Central, E: East, N: North, S: South, W: West, BBI: Bangka Belitung Islands, NT: Nusa Tenggara 
Although it is recommended a child aged 0-59 months is weighed at least eight times a year (i.e., four times over 6 months) (Indonesian Ministry of Health, 2015), only $41.2 \%$ of parents weighed their children four or more times during a 6 month period in 2010, ranging from 21.2\% (Jambi) to 86.6\% (Yogyakarta) across the provinces (Indonesian Ministry of Health, 2011).

Although there was no information about parents' smoking prevalence, in people aged 10 years and over, smoking prevalence was $28.5 \%$ in 2013 , and many smokers (82.5\%) were reported to smoke at home, ranging from $50.9 \%$ (Jakarta) to $92.4 \%$ (West Sulawesi) across the provinces (Indonesian Ministry of Health, 2013). Indonesia is reported to have the highest smoking prevalence for men $(76.2 \%$ in 2015) from 128 countries, whereas that for women is relatively low (3.6\% in 2015) (World Health Organization, 2017b).

\subsection{Early learning}

Our educational attainment findings revealed that although most children entered primary school (94.7\%), enrollment rates were relatively low for higher education, although they varied by province. The mean enrollment rate for junior high school was 70.7\% in 2013, ranging from $45.8 \%$ (Papua) to $83.3 \%$ (Riau Islands). The mean rate for high school was 55.2\% in 2013, ranging from 36.7\% (Papua) to 67.6\% (Riau Islands) (Indonesian Central Bureau of Statistics, n.d.-a).

\subsection{Security and safety}

Indonesia began developing the Jaminan Kesehatan Nasional, a national health insurance system, in 2014, which pools contributions from members and the government under a single health insurance agency (World Health Organization Regional Office for South-East Asia, 2017). Enrolled members include contributing beneficiaries and poor non-contributing beneficiaries (World Health Organization Regional Office for South-East Asia, 2017). The progressive expansion of coverage across the entire population is planned for completion by 2019 (World Health Organization Country Office for Indonesia, n.d.). The system offers outpatient and inpatient care at the primary level up to the tertiary level, excluding some care that is either partially covered or not covered (World Health Organization Regional Office for SouthEast Asia, 2017). However, another study noted that the spending focus is on curative care; thus, the budget allocation for preventive care is relatively low (World Health Organization Regional Office for South-East Asia, 2017). Moreover, health insurance coverage had only reached $66.5 \%$ of the population in 2016 (Indonesian Ministry of Health, 2017). Desa Siaga (alert village) programs are a community participation strategy in which villages use their own resources to recognize, prevent, and tackle problems to improve their health status, typically focusing on pregnancy and childbirth (Indonesian Ministry of Health, 2010b). This strategy is rooted in the idea that not only women but also all community members such as husbands, neighbors, community and religious leaders, and health professionals, play a role in promoting healthy pregnancies and safe deliveries. Elements of this strategy include notification, blood donation, transportation and communication, and financial support (Federal Ministry for Economic Cooperation and Development, 2011). For example, people who have vehicles assist other people with travel to healthcare facilities. Since 2010, it has been expanded to the Desa Siaga Akfif (active alert village) program, which includes village support to provide primary healthcare at health posts (World Health Organization Regional Office for South-East Asia, 2017). The Ministry of Health sets a target for $80 \%$ of villages to have Desa Siaga programs by 2015 (Indonesian Ministry of Health, 2010b). However, only $65.8 \%$ of villages had one in 2013, ranging from 2.0\% (West Papua) to $100 \%$ (Central Java) across the provinces (Indonesian Ministry of Health, 2014a).

\section{Discussion}

Overall, our results revealed several challenges for promoting ECD in Indonesia. Although the underfive mortality rate decreased between 2007 and 2012, it was still higher than the global average (42.5/1,000 live births) (World Health Organization, 2017b) and there were disparities between provinces. The limited availability of health services was an important factor, which may be associated with poor access to health facilities due to large catchment areas, limited responsiveness of parents while caregiving (e.g., no possession of the maternal and child health book, low frequency of child weighing, and high smoking prevalence at home), and limited higher-education opportunities for parents. These findings are consistent with previous studies that identified the importance of parents' responsive caregiving. The 
prevalence of stunting was negatively associated with weighing frequency at posyandus in rural Indonesia (Sahanggamu et al., 2017). This emphasizes the importance of continuously monitoring child growth in the community. Paternal smoking positively correlates with child malnutrition and mortality (Best et al., 2008; Semba et al., 2008), highlighting the importance of reducing the prevalence of paternal smoking and promoting paternal participation in child healthcare. It is important to improve parents' awareness of child health while also supporting the development of their childcare skills because parents act as the main decision makers when seeking healthcare for their children.

However, we also identified several important assets necessary to improve ECD, including community-based support systems such as community health posts, alert village programs, community volunteers, and larger numbers of nurses and midwives. Our findings underscore the importance of each village implementing a mutual assistance system to make it easier for people to access basic health services for their children.

Furthermore, to improve ECD in Indonesia, it is important to empower parents to utilize existing community health resources. To achieve this goal, nurses and midwives should promote enhanced awareness of child health and development in parents and the general population. Further research is required to better understand how to utilize these community assets to improve child health and development in Indonesia.

The limitation of this health statistics review was the cutoff year of 2013, which did not provide information about the current situation, due to the lack of availability of more recent statistics. Further research is needed to monitor and evaluate the ECD situation in Indonesia.

\section{Conclusions}

This study organized statistical health information across 33 Indonesian provinces to assess the ongoing challenges and existing assets for improving ECD. Our results indicated several challenges, including limited availability of health services, large catchment areas for puskesmas, parents' limited caregiving responsiveness, and limited opportunities for parents to achieve advanced education. Our results also revealed several important assets, including the existence of community health posts, alert village programs, community volunteers, and a large number of nurses and midwives.

Authorship contributions: Study Design; $\mathrm{MM}^{1}$ and $\mathrm{MM}^{2}$, Data Collection and Analysis; $\mathrm{MM}^{1}, \mathrm{MM}^{2}, \mathrm{HS}, \mathrm{R}, \mathrm{M}$, and HB, Manuscript Writing; MM1, MM², HS, R, M, and HB. All authors have reviewed and approved the final manuscript.

Short running title: Challenges and Assets: Early Childhood Development

Acknowledgments: This research was financially supported by the Japan Society for the Promotion of Science (JSPS) Grants-in-Aid for Scientific Research (Kakenhi) (grant number: 17H04471).

Conflicts of Interest: The authors declare no conflict of interest.

\section{References}

Adair, L. S., Fall, C. H. D., Osmond, C., Stein, A. D., Martorell, R., Ramirez-Zea, M., .. Victora, C. G. (2013). Associations of linear growth and relative weight gain during early life with adult health and human capital in countries of low and middle income: findings from five birth cohort studies. Lancet, 382(9891), 525-534. doi:10.1016/S0140-6736(13)60103-8

Andriani, H., Liao, C.-Y., \& Kuo, H.-W. (2016). Association of maternal and child health center (Posyandu) availability with child weight status in Indonesia: A national study. Int J Environ Res Public Health, 13(3), E293. doi:10.3390/ijerph13030293

Best, C. M., Sun, K., de Pee, S., Sari, M., Bloem, M. W., \& Semba, R. D. (2008). Paternal smoking and increased risk of child malnutrition among families in rural Indonesia. Tob Control, 17(1), 38-45. doi:http://dx.doi.org/10.1136/tc.2007.020875

Black, M. M., Walker, S. P., Fernald, L. C. H., Andersen, C. T., DiGirolamo, A. M., Lu, C., ... Grantham-McGregor, S. (2017). Early childhood development coming of age: science through the life course. Lancet, 389(10064), 77-90. doi:10.1016/S0140-6736(16)31389-7

Boothby, N., \& Stark, L. (2011). Data surveillance in child protection systems development: an Indonesian case study. Child Abuse Negl., 35(12), 993-1001. doi:10.1016/j.chiabu.2011.09.004

Britto, P. R., Lye, S. J., Proulx, K., Yousafzai, A. K., Matthews, S. G., Vaivada, T., ... Bhutta, Z. A. (2017). Nurturing care: promoting early childhood development. Lancet, 389(10064), 91-102. doi:10.1016/S0140-6736(16)313903 
Federal Ministry for Economic Cooperation and Development. (2011). Making childbirth a village affair: How 'Desa Siaga' improves the health of mothers and babies in Indonesia. Retrieved August 27, 2018, from http://health.bmz.de/what_we_do/Reproductive-maternal-and-child-

health/good_practices_and_tools/Making_childbirth_a_village_affair/index.jsp

Fernald, L. C. H., Kariger, P., Hidrobo, M., \& Gertler, P. J. (2012). Socioeconomic gradients in child development in very young children: evidence from India, Indonesia, Peru, and Senegal. Proc Natl Acad Sci USA, 109 Suppl 2, 17273-17280. doi:10.1073/pnas.1121241109

Hodge, A., Firth, S., Marthias, T., \& Jimenez-Soto, E. (2014). Location matters: trends in inequalities in child mortality in Indonesia. Evidence from repeated cross-sectional surveys. Plos One, 9(7), e103597-e103597. doi:10.1371/journal.pone.0103597

Indonesian Central Bureau of Statistics. (2008). Indonesia demographic and health survey 2007. Retrieved June 6, 2018, from http://microdata.worldbank.org/index.php/catalog/1403

Indonesian Central Bureau of Statistics. (2013). Indonesia demographic and health survey 2012. Retrieved June 6, 2018, from http://microdata.worldbank.org/index.php/catalog/1637

Indonesian Central Bureau of Statistics. (n.d.-a). Education. Retrieved June 6, 2018, from https://www.bps.go.id/subject/28/pendidikan.html\#subjekViewTab3

Indonesian Central Bureau of Statistics. (n.d.-b). Population. Retrieved June 6, 2018, from https://www.bps.go.id/subject/12/kependudukan.html\#subjekViewTab3

Indonesian Ministry of Health. (2004). Decree of Minister of Health No. 284/MENKES/SK/III/2004 regarding maternal and child health book. Retrieved June 6, 2018, from http://kesga.kemkes.go.id/images/pedoman/KEPMEN\%20284\%20buku\%20kia\%202014.pdf

Indonesian Ministry of Health. (2008a). Basic health research 2007. Retrieved June 6, 2018, from http://labdata.litbang.depkes.go.id/riset-badan-litbangkes/menu-riskesnas/menu-riskesdas

Indonesian Ministry of Health. (2008b). Indonesia health profile 2007. Retrieved June 6, 2018, from http://www.depkes.go.id/resources/download/pusdatin/profil-kesehatan-indonesia/

Indonesian Ministry of Health. (2010a). Basic health research 2010. Retrieved June 6, 2018, from http://labdata.litbang.depkes.go.id/riset-badan-litbangkes/menu-riskesnas/menu-riskesdas

Indonesian Ministry of Health. (2010b). Decree of Minister of Health No. 1529/MENKES/SK/X/2010 regarding general guidelines to develop active village and family. Retrieved June 6, 2018, from http://pusatkrisis.kemkes.go.id/_pub/files54175Pedoman_Pengembangan_Desa_dan_Kelurahan_Sia ga_Aktif.pdf

Indonesian Ministry of Health. (2011). Indonesia health profile 2010. Retrieved June 6, 2018, from http://www.depkes.go.id/resources/download/pusdatin/profil-kesehatan-indonesia/

Indonesian Ministry of Health. (2013). Basic health research 2013. Retrieved June 6, 2018, from http://labdata.litbang.depkes.go.id/riset-badan-litbangkes/menu-riskesnas/menu-riskesdas

Indonesian Ministry of Health. (2014a). Indonesia health profile 2013. Retrieved June 6, 2018, from http://www.depkes.go.id/resources/download/pusdatin/profil-kesehatan-indonesia/

Indonesian Ministry of Health. (2014b). Regulation of Minister of Health No.25 year 2014 regarding child health $\begin{array}{llll}\text { effort. Retrieved June } & 6, & 2018, & \text { from }\end{array}$ http://kesga.kemkes.go.id/images/pedoman/PMK\%20No.\%2025\%20ttg\%20Upaya\%20Kesehatan\%20An ak.pdf

Indonesian Ministry of Health. (2015). Ministry of Health strategic plan 2015-2019. Retrieved June 6, 2018, from http://www.depkes.go.id/resources/download/info-publik/Renstra-2015.pdf

Indonesian Ministry of Health. (2016). Regulation of Minister of Health No.43 year 2016 regarding minimum standard of health services. Retrieved June 6, 2018, from http://djsn.go.id/storage/app/uploads/public/58d/486/f01/58d486f010a3f067108647.pdf

Indonesian Ministry of Health. (2017). Indonesia health profile 2016. Retrieved June 6, 2018, from http://www.depkes.go.id/resources/download/pusdatin/profil-kesehatan-indonesia/

Irwin, L. G., Siddiqi, A., \& Hertzman, C. (2007). Early child development: A powerful equalizer. Retrieved October 12, 2018, from http://www.who.int/social_determinants/resources/ecd_kn_report_07_2007.pdf

Sahanggamu, P. D., Purnomosari, L., \& Dillon, D. (2017). Information exposure and growth monitoring favour child nutrition in rural Indonesia. Asia Pac J Clin Nutr, 26(2), 313-316. doi:10.6133/apjcn.012016.09

Schröders, J., Wall, S., Kusnanto, H., \& Ng, N. (2015). Millennium development goal four and child health inequities in Indonesia: A systematic review of the literature.Plos One, 10(5), e0123629-e0123629. doi:https://doi.org/10.1371/journal.pone.0123629

Semba, R. D., de Pee, S., Sun, K., Best, C. M., Sari, M., \& Bloem, M. W. (2008). Paternal smoking and increased risk of infant and under-5 child mortality in Indonesia. American Journal Of Public Health, 98(10), 1824-1826. doi:10.2105/AJPH.2007.119289 
United Nations Children's Fund. (2017). The state of the world's children 2017. Retrieved October 12, 2018, from https://www.unicef.org/publications/files/SOWC_2017_ENG_WEB.pdf

United Nations Statistics Division. (n.d.). SDG indicators. Retrieved June 6, 2018, from https://unstats.un.org/sdgs/metadata/

Victora, C. G., Adair, L., Fall, C., Hallal, P. C., Martorell, R., Richter, L., . . Sachdev, H. S. (2008). Maternal and child undernutrition: consequences for adult health and human capital. Lancet, 371(9609), 340-357. doi:10.1016/S0140-6736(07)61692-4

Winston, R., \& Chicot, R. (2016). The importance of early bonding on the long-term mental health and resilience of children. London Journal Of Primary Care, 8(1), 12-14. doi:10.1080/17571472.2015.1133012

World Health Organization. (2017a). Assessing and managing children at primary health-care facilities to prevent overweight and obesity in the context of the double burden of malnutrition. Retrieved October 12, 2018, from http://apps.who.int/iris/bitstream/handle/10665/259133/9789241550123-eng.pdf?sequence=1

World Health Organization. (2017b). World health statistics 2017: Monitoring health for the SDGs, Sustainable Development Goals. Retrieved June 6, 2018, from http://www.who.int/gho/publications/world_health_statistics/2017/en/

World Health Organization Country Office for Indonesia. (n.d.). Universal health coverage and health care financing Indonesia. Retrieved June 6, 2018, from http://www.searo.who.int/indonesia/topics/hs-uhc/en/

World Health Organization Regional Office for South-East Asia. (2017). The Republic of Indonesia health system review. Retrieved August 27, 2018, from http://apps.who.int/iris/handle/10665/254716 